ENTREPRENEURSHIP AND SUSTAINABILITY ISSUES

ISSN 2345-0282 (online) http://jssidoi.org/jesi/

2021 Volume 8 Number 4 (June)

http://doi.org/10.9770/jesi.2021.8.4(22)

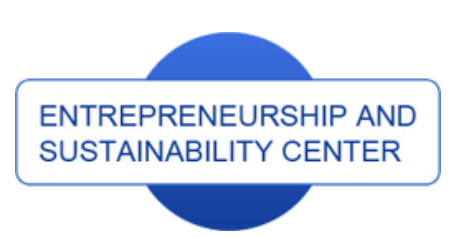

Publisher

$\underline{\text { http://jssidoi.org/esc/home }}$
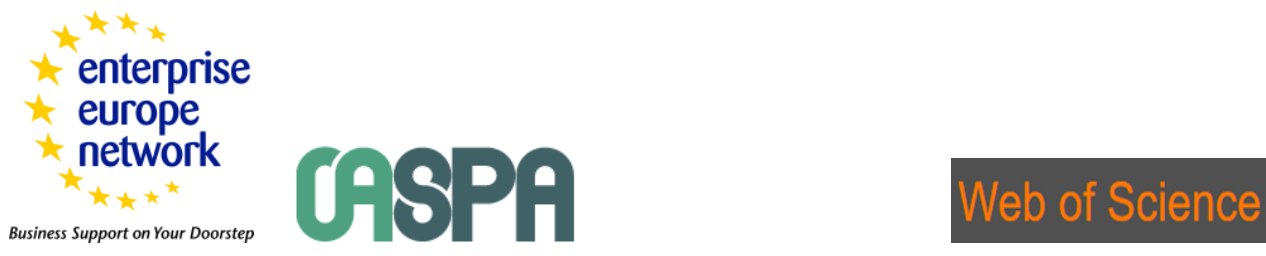

\title{
S Clarivate \\ INTRINSIC ALIGNMENT WITH STRATEGY AS A SOURCE OF BUSINESS SUSTAINABILITY IN SMES ${ }^{*}$
}

\author{
Romel Ramón González-Díaz ${ }^{1}$, Santos Lucio Guanilo Gómez ${ }^{2}$, Ángel Eduardo Acevedo-Duque ${ }^{3}$, \\ Jorge Suárez Campos ${ }^{4}$, Elena Cachicatari Vargas ${ }^{5}$ \\ ${ }^{1}$ Centro Internacional de Investigación y Desarrollo (CIID) Montería, Colombia \\ ${ }^{2,5}$ Universidad Nacional Jorge Basadre Grhomann-Tacna, Peru \\ ${ }^{3}$ Observatory of Public Policies, Autonomous University of Chile, Santiago 7500912, Faculty of Business and \\ Administration. Santiago, Chile \\ ${ }^{4}$ Facultad de Humanidades, Universidad Mayor de Chile, Santiago 7500994, Chile \\ ${ }^{1}$ director@ciid.com.co ; ${ }^{2}$ lguanilog@unjbg.edu.pe ; ${ }^{3}$ angel.acevedo@uautonoma.cl ; ${ }^{4}$ jorge.suarez@umayor.cl \\ 5ecachicatariv@unjbg.edu.pe
}

Received 15 November 2020; accepted 31 March 2021; published 30 June 2021

\begin{abstract}
This article presents an analysis of the degree of intrinsic alignment with the strategy as a source of business sustainability in the SMEs dedicated to the manufacturing sector in the region of Tacna, Peru. It was framed in a non-experimental research design of fieldtransaction, a survey was applied (questionnaire with 32 items with a Likert scale validated in the opinion of 3 experts with an Alpha Cronbach coefficient of 0.95 (Excellent) to a random sample of 247 directors and managers. The data were analyzed through the descriptive statistics (SPSS25) to know the behaviour of the variables under study. In order to test hypotheses, the chi-square statistic was applied (categorical variables, ordinals and unit of analysis greater than 30 subjects). The main findings show that the degree of intra-strategy alignment is 4.46 (excellent alignment of the Intrinsic with the strategy) and business sustainability resulted in 4.23 (high business sustainability). In conclusion, there is a relationship between the intrategy alignment and business sustainability in the SMEs of the manufacturing sector of the Tacna-Peru Region with a strength of 0.691 (strong relationship).
\end{abstract}

Keywords: Intrategy; strategy; business sustainability; SMEs; Covid-19; Industry 4.0

Reference to this paper should be made as follows: González-Díaz, R.R., Guanilo Gómez, S.L., Acevedo-Duque, A.E., Campos, J.S., Vargas, E.C. 2021. Intrinsic alignment with strategy as a source of business sustainability in SMEs. Entrepreneurship and Sustainability Issues, 8(4), 377-388. http://doi.org/10.9770/jesi.2021.8.4(22)

JEL Classifications: E30, E32

\footnotetext{
* This research was supported by the project, which has received funding from research and innovation programme of the Centro Internacional de Investigación y Desarrollo (CIID) Montería, Colombia.
} 


\section{ENTREPRENEURSHIP AND SUSTAINABILITY ISSUES}

ISSN 2345-0282 (online) http://jssidoi.org/jesi/

2021 Volume 8 Number 4 (June)

http://doi.org/10.9770/jesi.2021.8.4(22)

\section{Introduction}

The world is currently in the throes of a devastating health crisis and possibly unprecedented in recent decades, COVID-19 has one of the highest reproductive rates (1.5 to 3.5) that has ever challenged governments. To minimize this SARS-CoV-2 reproductive rate, Latin American governments have bet on social isolation measures to mitigate the wave of contagion that is putting public health systems in check. These actions have not only limited human interaction but have also fractured national productive systems (Khan \& Shanks, 2020; Yaya, Yaya, Otu, Otu, \& Labonté, 2020, Perret, \& García, 2020; González-Díaz, Acevedo-Duque, Salazar-Sepúlveda, \& Castillo, 2021).

The productive sector of goods and services has experienced a deep crisis that has generated an increase of more than $47.6 \%$ in the mortality rate of Latin American Small and Medium Enterprises (SMEs) (Brás-Dos-Santos \& Ramos Silva, 2020; Radicic, Pugh, \& Douglas, 2020, González-Díaz, Acevedo-Duque, Gómez, \& Cachicatari Vargas, 2021). However, there are SMEs that have reinvented their processes and have rethought on the basis of the new challenges of modernity and have balanced the theoretical aspects of strategic management with management practice (Peralta Miranda, Cervantes Atia, Salgado Herrera, \& Espinoza Pérez, 2020; Vörösmarty \& Dobos, 2020). In other words, to achieve this balance and overcome the new challenges of modern society, it is necessary to align internal and external aspects of SMEs to achieve effectiveness, productivity and finally, value creation, without losing sight of their peripheral vision, research, development and innovation (Elbanna, $\mathrm{Al}$ Katheeri, \& Colak, 2020; Filipishyna, Hryshyna, Zhuvahina, Ponedilchuk, \& Paska, 2020).

Deconstructing the key elements of a strategic business planning will allow revealing the neuralgic aspects intervening in the sustainable development of the SME, through a prospective retro analysis it is possible to leave in evidence the elements that confer value to the economic entity (Slavik, Hanak, \& Hudakova, 2020; Virglerova, Addeo, \& Zapletalikova, 2020; Vizzon, Do Carmo, Ceryno, \& Fiorencio, 2020). Hence, every SME needs to analyze the economic impact of management decisions (strategy), also needs to analyze how management decisions affect the unit level of the company (intrategy). Since management decisions have an impact not only on the economic outcome (profit), but also on the organizational outcome (unity), managers must evaluate their decisions from both strategic and intrinsic perspectives (Virglerova, Addeo, \& Zapletalikova, 2020, Ullah, Wu, Mehmood, Jabeen, Iftikhar, Acevedo-Duque, \& Kwan, 2021). Shareholders must share their interests with those of the employees, because only companies capable of achieving a high profit and unity level will survive in the long term (Sánchez, Villavicencio, \& Díaz, 2020).

In this sense, the alignment of the internal components (intrinsic) and external components (strategic) that the SME has, provides the dynamics of management and ensures its growth and sustainable development by creating value (Slavik, Hanak, \& Hudakova, 2020; Virglerova, Addeo, \& Zapletalikova, 2020; Vizzon, Do Carmo, Ceryno, \& Fiorencio, 2020, González-Díaz, Becerra-Peréz, \& Acevedo-Duque, 2020). By virtue of the above, it has become evident in the SMEs of the manufacturing sector in the Tacna-Peru Region that there are imbalances in their intrinsic and strategic alignment processes as a result of the health crisis (SARS-CoV-2) and it has been reflected in the studies presented by Bessa and Luz (2020); Singh and Singh (2020), which has resulted in a temporary closure of production centres, not having the option to access teleworking and has led to their definitive closure.

Therefore, this study aims to analyze the process of intrinsic alignment with the strategy as a source of business sustainability in the SMEs of the Tacna-Peru Region, which allows generating an analysis, reflection and at the same time a starting point to deepen it, enriched with new factors, by the new challenges of globalization(González-Díaz \& Becerra-Perez, 2021). For the analysis, the map of processes has been taken as a structure, which counts every organization, whether public or private, through a Newtonian relationship and 


\section{ENTREPRENEURSHIP AND SUSTAINABILITY ISSUES}

ISSN 2345-0282 (online) http://jssidoi.org/jesi/

2021 Volume 8 Number 4 (June)

http://doi.org/10.9770/jesi.2021.8.4(22)

through its three main blocks: the strategic, operative and support processes (Herrera \& Gómez, 2012, Vimal, Kandasamy, \& Duque, 2021).

Alignment is a common concept related (automotive mechanics) to the angular adjustments of tires for any reason during their useful life, this caused by various serious physical causes (shocks). Therefore, the process of alignment and balancing allows for an improvement in the performance of the wheels and the running of the vehicle. In other words, the alignment of business components (intrinsic and strategic) guarantees the proper functioning of the entity, by addressing the key processes of the administration such as planning, organization, management and control in the dynamics of the organizations (Gloria, Oscar, Mario, \& Roxani, 2020; Peralta Miranda et al., 2020; Ramírez, Lay, \& Sukier, 2020).

The creation of economic value for the shareholders of SMEs is one of the purposes of corporate financial management. However, to create a degree of commitment, loyalty and improve the production processes of factories, it is required to create value by integrating the actors that make life of the entity, thus ensuring business sustainability. To this end, this research presents a reflection that allows for the relationship between the strategy and the strategy to promote business sustainability in the manufacturing sector in the Tacna-Peru Region.

\section{Review of Scientific Literature}

This section presents a review of the scientific literature in terms of the components: intrategy, strategic and business sustainability. A precise conceptual and operational definition of these components is presented.

\subsection{Intrinsic strategy}

After reviewing the main databases (SCOPUS, WOS, SPRINGER), it was not possible to observe a conceptual definition of this word. However, it was possible to find the work presented by Soriano and Albiol (1998), who refers to the fact that the "intrinsic strategy" analyzes the impact of management decisions at the level of the organizational unit of the company. On the other hand, Petit Torres and Gutiérrez González (2007) and Cardona (2001) consider that strategies are management practices that have increased the level of unity in various companies. These strategies, if they are well aligned with the strategy of the SME, increase the capacity of the SME to achieve high performance and long life (González-Díaz, Gómez, et al., 2021; González-Díaz \& Ledesma, 2020; Hernández-Julio et al., 2020).

The strategy lists seven of these practices: job security, selective hiring, decentralization of decision making, contingent compensation, extensive training, few differences in status, and extensive financial and performance reporting (Cardona, 2001). This author warns that, for these practices to be successful, they need to be, first, internally consistent with each other and, second, externally consistent with the strategy. For the purpose of this study, strategy is studied under the three fundamental processes: 1) intrinsic strategy processes: this refers to the set of processes related to management decisions, 2) Support processes: these are the ones that coordinate the development and life cycle of the activities contained in the main processes, that is, the organizational processes and support the other processes, and 3) Operational processes: 3) Operational processes: they refer to the map of processes, together with the strategic processes and the support processes, they are those that are directly linked to the provision of the good or service to the client, such as the manufacturing of the product, the purchase management, the order system, the own attention(González-Díaz et al., 2020; González-Díaz, Gómez, et al., 2021). 


\section{ENTREPRENEURSHIP AND SUSTAINABILITY ISSUES}

ISSN 2345-0282 (online) http://jssidoi.org/jesi/

2021 Volume 8 Number 4 (June)

http://doi.org/10.9770/jesi.2021.8.4(22)

\subsection{Business strategies}

According to the scientific literature according to Finoti, Toaldo, Schwarzbach, and Marchetti (2019); Kiseleva, Sadovnikova, Karmanov, Kuznetsov, and Gasparian (2019); Muramalla and Al-Hazza (2019) agree that business strategies are a set of actions argued in terms of business objectives, supported by three fundamental elements: The diagnosis (What is happening here?); policies that guide; and coherent actions. The strategist will have to choose which activity or activities he will dedicate his maximum effort to and face all the possible adversities or obstacles that will arise. As Kiseleva et al. (2019) say, it is a gamble, and that option to which he has bet must be the best, in his opinion and real criterion, therefore he will need to put all his efforts in order to achieve those objectives. The obstacles that may arise are related to government policies, competitor strategies, client decisions, changes in the environment, among others.

\subsection{Intrinsic Alignment}

To build a solid strategy that allows overcoming the challenges of growth and development considers that every managerial decision has, whether it wants or not, strategic consequences in terms of greater or lesser economic or social benefit and intrinsic consequences in terms of optimization of its resources, highlighting the main driver as it is the workforce, followed by technology (Saiz-Álvarez, Vega-Muñoz, Acevedo-Duque, \& Castillo, 2020, Lima \& Dallari, 2020; Peralta Miranda, Cervantes Atia, Salgado Herrera, \& Espinoza Pérez, 2020). The elaboration of a business action plan must be supported by the organizational needs and a clear articulation of the intrinsic and strategic (Cardona, 2001). In this research, the alignment between the intrinsic and the strategic marks a synergy that benefits the business action because the organizational unit responds effectively to the vicissitudes of modernity. Otherwise, the SME is immersed in incompatibilities between operational, tactical and strategic guidelines.

\subsection{Corporate Sustainability}

Lesnikova and Schmidtova (2020), Sukawati, Riana, Rajiani, and Abbas (2020) agree that business sustainability is a multidimensional concept and is not solved by a single corporate action. Companies are faced with the challenge of minimizing waste from ongoing operations and preventing pollution, along with the reorientation of their portfolio of competencies towards more sustainable technologies and technologically clean competencies. On the other hand, Lee (2020) believes that the company that creates value at the level of strategies and practices moves towards a more sustainable world with a degree of operational efficiency and that proactive measures in the environment can produce long-term gains.

In this research, corporate sustainability focuses on developing a human-scale profitability formula that, by connecting with all stakeholders and the natural environment, operates in tune with social progress and in harmony with planetary limits by focusing on reasonable returns and profits, rather than steady growth (Ahlström, Williams, \& Vildåsen, 2020; Prasad, Acevedo-Duque, Argüello, Pineda, \& Turcios, P. 2020, Mishra, \& Bapat, 2019). In other words, SMEs with business sustainability have multiple orientations (environmental, social, governance and financial), ensuring long-term business success, contributing to economic and social development and protecting the environment (González-Díaz, Acevedo-Duque, et al., 2021). 


\section{Methodology}

In the present study, it was framed in a non-experimental research design of field - transversal (González-Díaz \& Hernández-Royett, 2017; González-Díaz \& Polo, 2017). A survey was applied (questionnaire with 32 items with a Likert scale validated in the opinion of 3 experts with a Cronbach's Alpha coefficient of 0.95(Excellent) to a random sample with a margin of error of $5 \%$ with a confidence level of $95 \%$, for a total of 247 directors and managers of SMEs in the manufacturing sector of the Tacna-Peru Region. The data were analyzed through descriptive statistics (SPSS25) to know the behaviour of the variables under study. Likewise, to test hypotheses, the chi-square statistic was applied (categorical variables, ordinals and unit of analysis greater than 30 subjects), according to the following system:

- $\mathrm{H} 0=$ There is no relationship between the Intrinsic alignment and business sustainability SMEs in the manufacturing sector in the Tacna-Peru Region.

- $\quad \mathrm{H} 1=$ There is a relationship between the Intrinsic Alignment and the sustainability of the manufacturing SMEs in the Tacna-Peru Region.

- Asymptotic significance (bilateral): 0.005

- If H1 is accepted, the contingency coefficient is considered to measure the intensity of the relationship between variables.

Additionally, the criteria for data interpretation are presented in the following table 1.

Table 1. Interpretation Criteria Results

\begin{tabular}{ccc|l} 
& & \multicolumn{2}{c}{ Interpretation } \\
\cline { 3 - 4 } Cut-off points & Data range & Intrathegic Alignment & \multicolumn{1}{c}{ Business Sustainability } \\
$\mathbf{1}$ & $1,00-1,80$ & Poor Intrathegic Alignment & Poor business sustainability \\
$\mathbf{3}$ & $1,81-2,60$ & Low Intrathegic Alignment & Low business sustainability \\
$\mathbf{4}$ & $2,61-3,40$ & Regular Intrathegic Alignment & Regular business sustainability \\
$\mathbf{5}$ & $3,41-4,20$ & High Intrathegic Alignment & High business sustainability \\
Excellent business sustainability
\end{tabular}

\section{Analysis and discussion of results}

Once the data was collected, the results were analyzed and discussed with the intention of analyzing the variables: intrategy alignment and business sustainability. For this purpose, the analysis of the results on the intra-strategy alignment is initially presented through the degree of alignment of the Intrastrategy with the strategy of the SME. Then an analysis of business sustainability is made from the perception of the managers of the SMEs dedicated to manufacturing. Finally, the test statistic (chi-square) was applied to determine the existence of a relationship between the variables mentioned above. Likewise, the contingency coefficient was applied to determine the strength of the relationship between the variables. 
ENTREPRENEURSHIP AND SUSTAINABILITY ISSUES

ISSN 2345-0282 (online) http://jssidoi.org/jesi/

2021 Volume 8 Number 4 (June)

http://doi.org/10.9770/jesi.2021.8.4(22)

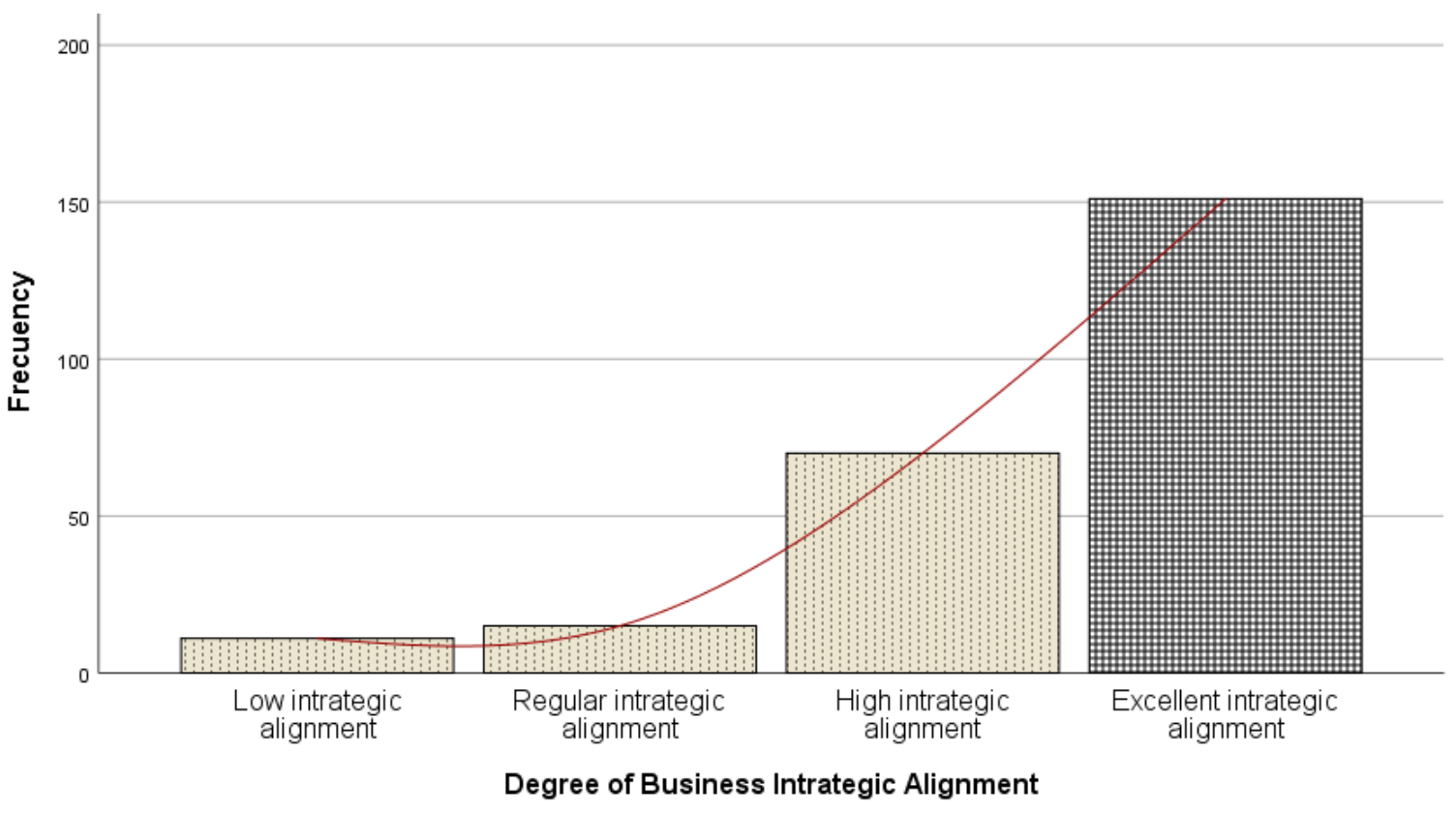

Figure 1. Degree of Business Intrategy Alignment in SMEs

Figure 1 shows the degree of strategic business alignment in the SMEs dedicated to manufacturing in the city of Tacna, Peru, which is concentrated in $61.1 \%$ (excellent), 28.3\% (high), 6.1\% (regular) and 4.5\% (low) Intrinsic alignment. Additionally, it presents as a minimum data: 2 and maximum data: 5 , with a standard deviation of 0,800 for an average of 4,46 and according to the table 1 referred to the criteria of interpretation of the results it is categorized as an excellent alignment of the Intratégica with the strategy of the SMEs of the manufacturing sector. According to Lima and Dallari (2020); Peralta Miranda, Cervantes Atia, Salgado Herrera, and Espinoza Pérez (2020) agree with these results because the SMEs with an alignment of their organizational unit with the institutional directions confer organizational synergy with a coupling characterized by loyalty and commitment to the entity.

However, there are studies such as Arroyo-Huayta, Cruces-Raimudis, Viacava-Campos, Leon-Chávarri, and Aderhold (2021); Durand-Sotelo, Monzon-Moreno, Chavez-Soriano, Raymundo-Ibañez, and Dominguez (2020); Huallpa, Vera, Altamirano, Raymundo, and Moguerza (2019) who agree that in Peru, the production systems of SMEs dedicated to manufacturing do not keep their strategies aligned with the strategies, which has generated a delay in organizational adjustments due to the economic crisis that is currently submerging the world with the pandemic.

Based on this, the researchers of this study reflect on this divergence and agree that sometimes managers or leaders of SMEs in the region of Tacna, Peru, have been associating the concept of intrategy as an implicit part of the improvised actions to respond to SMEs, because the newspaper Gestion (2020) in a joint statement between the Association of SMEs, Lima Chamber of Commerce, Confiep, Perucamaras, Amcham and the regional chambers of Ica, Cajamarca, Arequipa, La Libertad, Tacna and Lambayeque, expressed their commitment to the economic and productive reactivation, recognizing the diverse organizational problems given by the confinement measures and the emergence of teleworking which has been a relevant strategy in the service sector, a situation that has not benefited the manufacturing sector (Cespedes-Pino, Hurtado-Laguna, Macassi-Jaurequi, RaymundoIbañez, \& Dominguez, 2020; Henríquez-Alvarado, Luque-Ojeda, Macassi-Jauregui, Alvarez, \& RaymundoIbañez, 2019; Huallpa, Vera, Altamirano, Raymundo, \& Moguerza, 2019). 


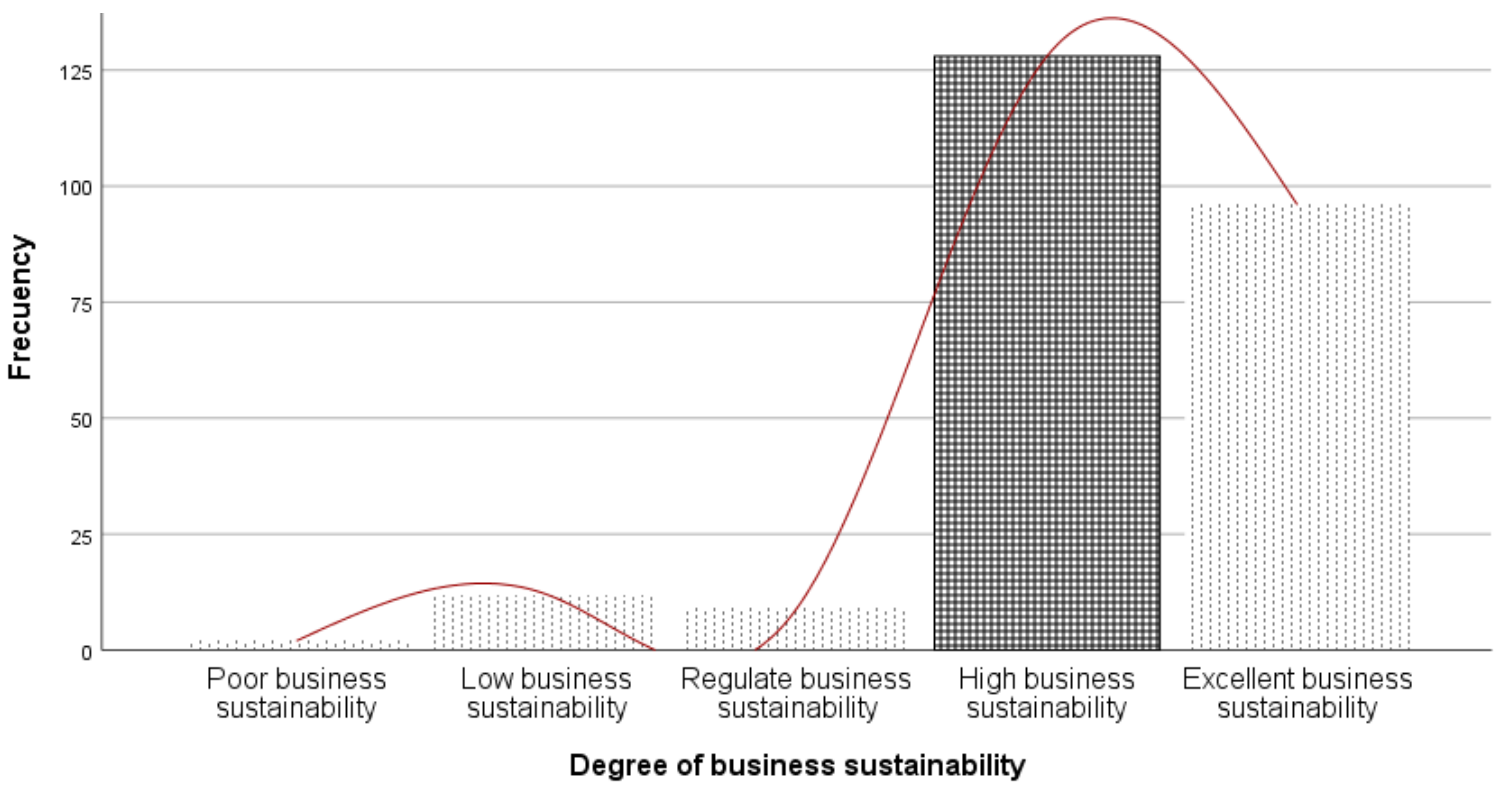

Figure 2. Degree of business sustainability in SMEs

Figure 2 shows the degree of business sustainability of SMEs in the Tacna region of Peru, which is concentrated in $51.8 \%$ (high), $38.9 \%$ (excellent), $4.9 \%$ (low), (3.6\%), and (0.8\%). Likewise, it presents as a minimum data: 1 and a maximum data: 5, with a standard deviation of 0.801 and an average of 4.23 and according to table 1 referring to the criteria of interpretation of the results it is categorized as High business sustainability of the SMEs of the manufacturing sector. These results coincide with the ideas of Peñaflor-Guerra, Sanagustín-Fons, and Ramírez-Lozano (2020), who consider the dichotomy between ethics and social sustainability.

According to Agenda 2030, Peru is committed to eradicating poverty, protecting the planet and ensuring prosperity through the 17 Sustainable Development Goals (SDAs), as a clear guide for action on global needs in solutions with a shared vision. In this context, Hannan et al. (2020) and Fuentes et al. (2019) consider that in order to achieve the ODS, not only public agencies must be committed, but also SMEs must be involved in the production chain, in order to provide a favourable dynamic for the country's economic development. Consequently, the manufacturing sector has been fractured by the confinement measures taken by the Peruvian government on the occasion of the COVID-19. Therefore, the managers and/or directors of the SMEs in the manufacturing sector assume empirical sustainability policies in the development of their productive activities.

Once the descriptive statistics were applied, Pearson's Chi-square test statistic was calculated in order to find out if there is a relationship between the degree of intrinsic alignment and business sustainability in the SMEs, for which the following result was obtained as described in table 2. 


\section{ENTREPRENEURSHIP AND SUSTAINABILITY ISSUES}

ISSN 2345-0282 (online) http://jssidoi.org/jesi/

2021 Volume 8 Number 4 (June)

http://doi.org/10.9770/jesi.2021.8.4(22)

Table 2. Calculation of chi-square test statistics and contingency coefficient

\begin{tabular}{l|r|r|r} 
& Value & Mexico City & $\begin{array}{c}\text { Asymptotic (bilateral) } \\
\text { significance }\end{array}$ \\
\hline Pearson's Chi-square & $225,164^{\mathrm{a}}$ & 12 &, 000 \\
\hline Reason for plausibility & 148,705 & 12 &, 000 \\
\hline Linear-to-linear association & 121,332 & 1 &, 000 \\
\hline Contingency coefficient &, 691 & 247 &, 000 \\
\hline N of Valid cases & & \\
\hline
\end{tabular}

a. 11 boxes $(55.0 \%)$ have expected a count less than 5 . The expected minimum count is .09 .

Table 2 shows the symmetric measures and the results of the chi-square test with an asymptotic (bilateral) significance of 0.000 less than the accepted significance level (0.005). Therefore, the null hypothesis is rejected, and the alternative hypothesis is accepted, which establishes that there is a relationship between the Intrinsic Alignment and business sustainability in the SMEs of the manufacturing sector of the Tacna-Peru Region. Depending on the existence of a relationship, the contingency coefficient was calculated to measure the strength of this relationship, which resulted in 0.691 (strong relationship). Likewise, this relationship can be seen in a more extensive way in figure 3.

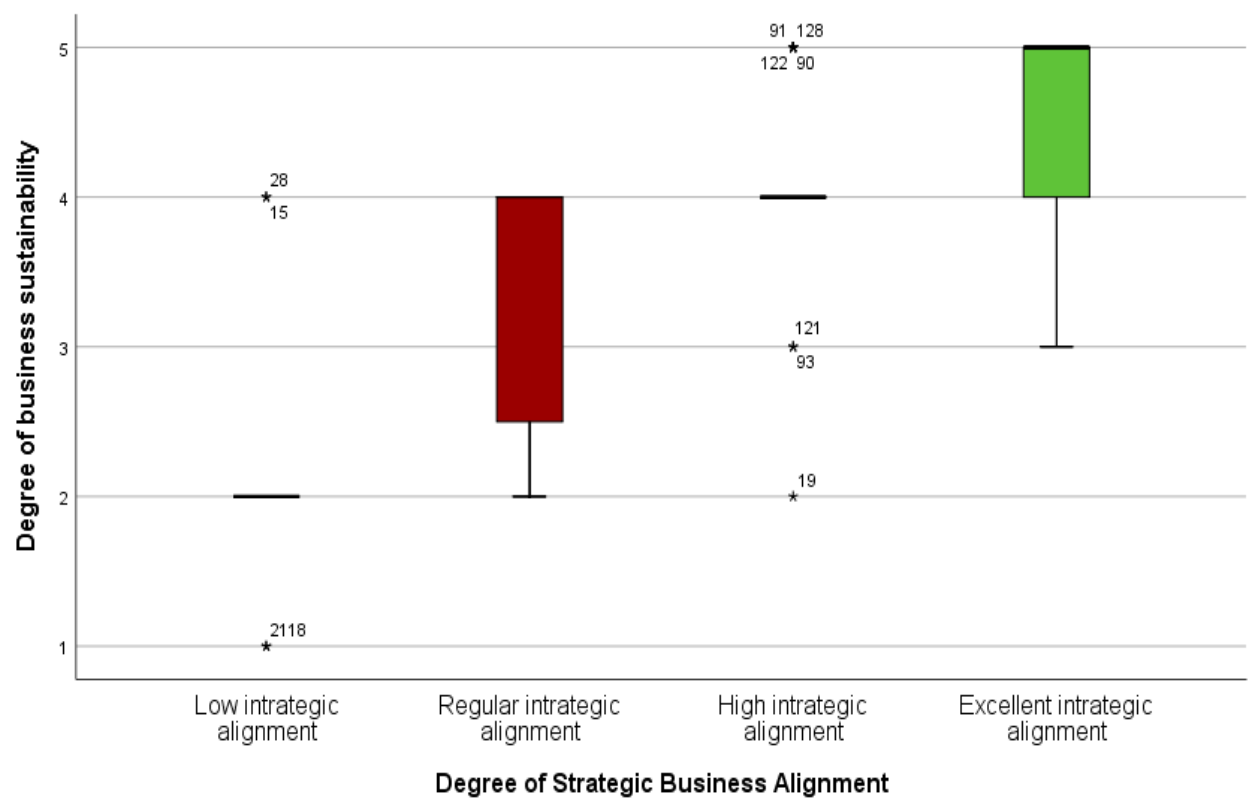

Figure 3. Relationship between the degree of intrategy alignment and business sustainability in SMEs

Figure 3 shows the box and whiskers diagram of the 247 values grouped together, which illustrate the relationship between the degree of intrinsic alignment and business sustainability in SMEs. The significant findings of the variable degree of intrategy alignment with a mean of 4.46, a median and fashion of 5.00, with a standard deviation of 0.800 , a variance of 0.640 with values distributed in a minimum of 2 and a maximum of 5 . On the other hand, the variable business sustainability with a mean of 4.23 , a median and fashion of 4.00 , with a standard deviation of 0.801 , a variance of 0.642 with values distributed in a minimum of 1 and a maximum of 5 .

Both variables with a strong ratio of 0.691 according to the contingency coefficient, with a concentration of the data the excellent degree of intrinsic alignment that provides values above 4 (High and Excellent) business sustainability. Likewise, the data has a close grouping in the regular degree of intrategy alignment with values 


\section{ENTREPRENEURSHIP AND SUSTAINABILITY ISSUES}

ISSN 2345-0282 (online) http://jssidoi.org/jesi/

2021 Volume 8 Number 4 (June)

http://doi.org/10.9770/jesi.2021.8.4(22)

between (2-4) concentrated in the regular and high business sustainability categories. Finally, the existence of 11 outliers detailed below: Low degree of intrategy alignment (21, 18, 28 and 15), High degree of strategic alignment $(19,93,121,91,128,90,122)$. So that managers and/or directors enhance their positions based on the contribution of economic generation $(44.50 \%)$, social contribution $(30.30 \%)$ and environmental protection $(25.20 \%)$ as the components that guarantee long-term business success.

The above results reflect a strong relationship between the degree of intrategy alignment and business sustainability in the SMEs in the region of Tacna, Peru. In other words, SMEs dedicated to manufacturing make efforts to align organizational structure and organizational behaviour in every execution of corporate strategies. This leads to organizational harmony that creates synergies in work teams that are motivated to achieve business objectives. These results are consistent with the approaches of Ghobakhloo and Fathi (2020); Puspitaningtyas (2020) and Fuentes et al. (2019) who consider some strategies to maintain harmony among the members of the organization, modern management, good financial practice in the development of operations, taking advantage of technological resources (IT) to develop digitally adjusted manufacturing systems to confer sustained competitiveness in the era of Industry 4.0 in its absence survival in the era COVID-19 and Post-COVID-19.

\section{Conclusions}

On the basis of the results presented, it is determined that there is a strong positive relationship between the degree of intra-strategic alignment and business sustainability in the SMEs dedicated to the manufacturing sector in the region of Tacna, Peru. Modernity has brought with it a technological transition (Industry 4.0), new diseases (COVID-19) and other political, economic and social processes that distinguish the Latin American reality, where SMEs dedicated to manufacturing are trying to overcome the challenges of the 21 st century by resorting to intraregional alignment with strategy as a source of business sustainability. Specifically, there is a vision of an intrastrategic route characterized by a rapid response to the managerial decisions of the productive entity. This will allow the dynamization of the productive cycle without neglecting the pre-established strategic plans.

Business sustainability will be given in terms of harmonizing the internal structural aspects of the SME and the route mapped out for achieving the objectives. This involves applying strategies for profitability (economic), human capital training (human), technological infrastructure (ICT), social responsibility (social) and environmental protection (environmental).

\section{References}

Acevedo-Duque, Á., Argüello, A., Pineda, B. y Turcios, P. (2020). Competencias del docente en educación online en tiempo de COVID-19: (Teacher's competencies in online education in time of COVID-19). Universidades Públicas de Honduras. Revista de Ciencias Sociales (Ve), XXVI (Número especial 2), 206-224

Ahlström, H., Williams, A., \& Vildåsen, S. S. (2020). Enhancing systems thinking in corporate sustainability through a transdisciplinary research process. Journal of Cleaner Production, 256. doi:10.1016/j.jclepro.2020.120691

Arroyo-Huayta, C., Cruces-Raimudis, S., Viacava-Campos, G., Leon-Chávarri, C., \& Aderhold, D. (2021) Model to improve the efficiency in the extrusion area in a manufacturing sme of the industrial plastic sector based on smed, autonomous maintenance and $5 \mathrm{~s}$. In: Vol. 1253 AISC (pp. 545-551): Springer.

Bessa, K., \& Luz, R. A. D. (2020). The covid-19 pandemic and regional particularities of its diffusion in the urban network segment in the state of Tocantins, Brazil. Atelie Geografico, 14(2), 6-28. doi:10.5216/ag.v14i2.63987

Brás-Dos-Santos, A., \& Ramos Silva, J. (2020). The importance of Latin American space in the internationalization of Portuguese SMEs. Janus.net, 11(1), 77-97. doi:10.26619/1647-7251.11.1.6

Cardona, S. (2001). Intrategia: una dimensión básica de la cultura empresarial (Intrategy: a basic dimension of corporate culture). En Álvarez.

Cespedes-Pino, R., Hurtado-Laguna, J., Macassi-Jaurequi, I., Raymundo-Ibañez, C., \& Dominguez, F. (2020). LEAN Production Management Model based on Organizational Culture to Improve Cutting Process Efficiency in a Textile and Clothing SME in Peru. IOP Conference Series Materials Science and Engineering 796:012004 


\section{ENTREPRENEURSHIP AND SUSTAINABILITY ISSUES}

ISSN 2345-0282 (online) http://jssidoi.org/jesi/

2021 Volume 8 Number 4 (June)

http://doi.org/10.9770/jesi.2021.8.4(22)

Corporate Social Responsibility on Regional Attachment in Sports: Three-Wave Indirect Effects of Spectators' Pride and Team Identification. Sustainability 2021, 13, 597. doi:10.3390/su13020597

doi: 10.1088/1757-899X/796/1/012004

Durand-Sotelo, L., Monzon-Moreno, M., Chavez-Soriano, P., Raymundo-Ibañez, C., \& Dominguez, F. (2020). Lean production management model under the change management approach to reduce order fulfillment times for Peruvian textile SMEs. IOP Conference Series Materials Science and Engineering 796:012023 doi: 10.1088/1757-899X/796/1/012023

Elbanna, S., Al Katheeri, B., \& Colak, M. (2020). The harder firms practice strategic management, the better they are. Strategic Change, 29(5), 561-569. doi:10.1002/jsc. 2365

Filipishyna, L., Hryshyna, L., Zhuvahina, I., Ponedilchuk, T., \& Paska, I. (2020). Model scenarios of sustainable development strategy in the formulation of mechanisms for enterprise support resources. Intellectual Economics, 14(1), 31-44. doi:10.13165/IE-20-14-1-02

Finoti, L. L., Toaldo, A. M. M., Schwarzbach, L. C., \& Marchetti, R. Z. (2019). Marketing strategy process: Analyzing the sequential relationships among its strategic activities. Revista Brasileira de Gestao de Negocios, 21(5), 767-787. doi:10.7819/rbgn.v21i5.4031

Fuentes, D., Toscano, H., \& Sepúlveda, V. (2019). Enterprise Sustainability: Literature Review in the Context of SMEs Worldwide. Revista Opción de La Universidad del Zulia, 35(25), 1526-1558.

Gestión. (2020). Gremios empresariales se comprometen a priorizar la salud en reactivación económica (Business unions commit to prioritize health in economic reactivation). Retrieved from https://gestion.pe/economia/gremios-empresariales-se-comprometen-a-priorizar-la-saluden-reactivacion-economica-noticia/

Ghobakhloo, M., \& Fathi, M. (2020). Corporate survival in Industry 4.0 era: the enabling role of lean-digitized manufacturing. Journal of Manufacturing Technology Management, 31(1), 1-30. doi:10.1108/JMTM-11-2018-0417

Gloria, N. A., Oscar, N. D. G., Mario, G., \& Roxani, K. Z. (2020). Corporate entrepreneurship and innovation: A two-way link. Revista Venezolana de Gerencia, 25(3), 524-544. doi:10.37960/rvg.v25i3.33387

González-Díaz, R. R., \& Becerra-Perez, L. A. (2021). Stimulating Components for Business Development in Latin American SMEs. In Á. Rocha, H. Adeli, G. Dzemyda, F. Moreira, \& A. M. Ramalho Correia, Trends and Applications in Information Systems and Technologies Cham.

González-Díaz, R. R., \& Hernández-Royett, J. (2017). Diseños de investigación cuantitativos aplicados en las ciencias de la administración y gestión (Quantitative Research Designs Applied in Administration and Management Sciences). Globalciencia, 3(1), 15-27.

González-Díaz, R. R., \& Ledesma, K. N. F. (2020). Cultura organizacional y Sustentabilidad empresarial en las Pymes durante crisis periodos de confinamiento social (Organizational culture and business sustainability in SMEs during crisis periods of social confinement). CIID Journal, 1(1), 28-41.

González-Díaz, R. R., \& Polo, E. A. S. (2017). Estrategias gerenciales para la innovación en instituciones educativa públicas (Management strategies for innovation in public educational institutions). Journal Latin American Science, 1(1), 1-23.

González-Díaz, R. R., Acevedo-Duque, Á. E., Flores-Ledesma, K. N., Cruz-Ayala, K., \& Guanilo Gomez, S. L. (2021). Knowledge Management Strategies Through Educational Digital Platforms During Periods of Social Confinement. In Á. Rocha, H. Adeli, G. Dzemyda, F. Moreira, \& A. M. Ramalho Correia, Trends and Applications in Information Systems and Technologies Cham.

González-Díaz, R. R., Becerra-Peréz, L. A., \& Acevedo-Duque, A. E. (2020). Narco-Marketing como estrategia para el desarrollo turístico local (Narco-Marketing as a strategy for local tourism Development). Revista Ibérica de Sistemas e Tecnologias de Informação, (E36), 7185.

González-Díaz, R. R., Gómez, S. L. G., Vegas-Ochoa, J. C., \& Vargas, E. C. (2021). Teaching Accompaniment in Colombia's Official Educational Institutions. Education, 1, 2.

González-Díaz, R., Vásquez Llamo, C. E., Hurtado Tiza, D. R., \& Menacho Rivera, A. S. (2020). Plataformas interactivas y estrategias de gestión del conocimiento durante el Covid-19 (Interactive platforms and knowledge management strategies during Covid-19). Revista Venezolana de Gerencia, 25(4), 68-81. https://produccioncientificaluz.org/index.php/rvg/article/view/35177

González-Díaz, R.R., Acevedo-Duque, A.E., Gómez, S.L.G., Cachicatari Vargas, E. (2021). Business counterintelligence as a protection strategy for SMEs. Entrepreneurship and Sustainability Issues, 8(3), 340-352.

González-Díaz, R.R.; Acevedo-Duque, Á.; Salazar-Sepúlveda, G.; Castillo, D. (2021) Contributions of Subjective Well-Being and Good Living to the Contemporary Development of the Notion of Sustainable Human Development. Sustainability, 13, 3298. doi: $10.3390 /$ su13063298

Hannan, M. A., Hossain Lipu, M. S., Akhtar, M., Begum, R. A., Al Mamun, M. A., Hussain, A., . . Basri, H. (2020). Solid waste collection optimization objectives, constraints, modeling approaches, and their challenges toward achieving sustainable development goals. Journal of Cleaner Production, 277. doi:10.1016/j.jclepro.2020.123557

Henríquez-Alvarado, F., Luque-Ojeda, V., Macassi-Jauregui, I., Alvarez, J. M., \& Raymundo-Ibañez, C. (2019). Process optimization using lean manufacturing to reduce downtime: Case study of a manufacturing SME in Peru.

Hernández-Julio, Y. F., Meriño-Fuentes, I., González-Díaz, R. R., Guerrero-Avendaño, A., Toledo, L. V. O., \& Bernal, W. N. (2020, 24-27 June 2020). Fuzzy knowledge discovery and decision-making through clustering and Dynamic tables: Application in Colombian business Finance. 2020 15th Iberian Conference on Information Systems and Technologies (CISTI),

Herrera, T. F., \& Gómez, J. M. (2012). Diseño de un sistema integrado de gestión para el sector empresarial de las pymes (Design of an integrated management system for the business sector of SMEs). Aglala, 3(1), 65-80.

doi: 10.9770/jesi.2021.8.3(21)

Huallpa, J., Vera, T., Altamirano, E., Raymundo, C., \& Moguerza, J. M. (2019) Production management model for increasing productivity in bakery SMEs in Peru. In: Vol. 971 (pp. 477-485): Springer Verlag. 


\section{ENTREPRENEURSHIP AND SUSTAINABILITY ISSUES}

ISSN 2345-0282 (online) http://jssidoi.org/jesi/

2021 Volume 8 Number 4 (June)

http://doi.org/10.9770/jesi.2021.8.4(22)

Khan, M., \& Shanks, S. (2020). Decolonising COVID-19: delaying external debt repayments. The Lancet Global Health, 8(7), e897. doi:10.1016/S2214-109X(20)30253-9

Kiseleva, I. A., Sadovnikova, N. A., Karmanov, M. V., Kuznetsov, V. I., \& Gasparian, M. S. (2019). Developing the business strategy for a consulting company. International Journal of Recent Technology and Engineering, 8(2), 3834-3838. doi:10.35940/ijrte.B2465.078219

Lee, S. H. (2020). Achieving corporate sustainability performance: The influence of corporate ethical value, and leader-member exchange on employee behaviors and organizational performance. Fashion and Textiles, 7(1). doi:10.1186/s40691-020-00213-w

Lesnikova, P., \& Schmidtova, J. (2020). Development of Corporate Sustainability in Enterprises through the Application of Selected Practices and Tools. Organizacija, 53(2), 112-126. doi:10.2478/orga-2020-0008

Lima, J., \& Dallari, S. (2020). The global strategy on public health, innovation and intellectual property: Establishment of a priority order for research and development needs in Brazil. Saude e Sociedade, 29(2), 1-13. doi:10.1590/S0104-12902020181162

Muramalla, V. S. S. R., \& Al-Hazza, A. M. (2019). Entrepreneurial strategies and factors stimulate the business of tech startups. International Journal of Financial Research, 10(3), 360-370. doi:10.5430/ijfr.v10n3p360

Peñaflor-Guerra, R., Sanagustín-Fons, M. V., \& Ramírez-Lozano, J. (2020). Business ethics crisis and social sustainability. The case of the product "Pura Vida" in Peru. Sustainability (Switzerland), 12(8). doi:10.3390/SU12083348

Peralta Miranda, P., Cervantes Atia, V., Salgado Herrera, R., \& Espinoza Pérez, A. (2020). Strategic planning for the innovation of small and medium enterprises in the city of barranquilla-Colombia. Revista Venezolana de Gerencia, 25(89), 229-243. doi:10.37960/revista.v25i89.31380

Perret, A., \& García, R. (2020). Desafíos jurídicos planteados por la guerra contra las drogas y la lucha contra el crimen organizado en Colombia (Legal challenges posed by the war on drugs and the fight against organized crime in Colombia), Jurídicas CUC, 16(1), 371-390. doi: 10.17981/juridcuc.16.1.2020.1

Petit Torres, E. E., \& Gutiérrez González, L. B. (2007). Empowerment leadership: Promoter of innovation. Revista Venezolana de Gerencia, 12(38), 207-217. $\quad$ Retrieved from https://www.scopus.com/inward/record.uri?eid=2-s2.034548108653\&partnerID=40\&md5=3fa706e9d334396bc444e42bf7c04247

Prasad, M., Mishra, T., \& Bapat, V. (2019). Corporate social responsibility and environmental sustainability: Evidence from India using energy intensity as an indicator of environmental sustainability. IIMB Management Review, 31(4), 374-384. doi:10.1016/j.iimb.2019.07.014

Puspitaningtyas, Z. (2020). Sustainability of family business in perspective of financial accounting. International Journal of Scientific and Technology Research, 9(2), 1585-1589. Retrieved from https://www.scopus.com/inward/record.uri?eid=2-s2.085079552470\&partnerID $=40 \& m d 5=8 \mathrm{c} 7 \mathrm{~d} 57 \mathrm{e} 4 \mathrm{abaffb} 150 \mathrm{cf0f005b4165c12}$

Radicic, D., Pugh, G., \& Douglas, D. (2020). Promoting cooperation in innovation ecosystems: evidence from European traditional manufacturing SMEs. Small Business Economics, 54(1), 257-283. doi:10.1007/s11187-018-0088-3

Ramírez, R. I., Lay, N. D., \& Sukier, H. B. (2020). Management strategy for people management in the mining sector of Venezuela, Colombia and Chile. Informacion Tecnologica, 31(1), 133-140. doi:10.4067/S0718-07642020000100133

Saiz-Álvarez, J.M., Vega-Muñoz, A., Acevedo-Duque, Á. \& Castillo, D. (2020) B Corps: A Socioeconomic Approach for the COVID-19 Postcrisis. Front. Psychol. 11:1867. doi: 10.3389/fpsyg.2020.01867

Sánchez, J. G. N., Villavicencio, M. N., \& Díaz, R. R. G. (2020). Ética sindical como mecanismo impulsor de competitividad en las pequeñas y medianas empresas (Trade union ethics as a competitiveness driver in small and medium-sized enterprises). Utopía y praxis latinoamericana: revista internacional de filosofía iberoamericana y teoría social (3), 154-173.

Singh, I., \& Singh, J. (2020). Income and Employment Changes under COVID-19 Lockdown: A Study of Urban Punjab. Millennial Asia. doi:10.1177/0976399620957630

Slavik, S., Hanak, R., \& Hudakova, I. M. (2020). Natural and generic strategies of start-ups and their efficiency. Journal of Competitiveness, 12(2), 125-148. doi:10.7441/joc.2020.02.08

Soriano, P. C., \& Albiol, M. N. C. (1998). Intrategia. Harvard Deusto business review (85), 36-41.

Sukawati, T. G. R., Riana, I. G., Rajiani, I., \& Abbas, E. W. (2020). Managing corporate sustainability by revitalizing Balinese cultural identity. Polish Journal of Management Studies, 21(1), 382-393. doi:10.17512/pjms.2020.21.1.28

Ullah, F., Wu, Y., Mehmood K., Jabeen, F., Iftikhar, Y., Acevedo-Duque, Á., \& Kwan, H.K. (2021) Impact of Spectators' Perceptions of

Vimal, K. E. K., Kandasamy, J., \& Duque, A. A. (2021). Integrating sustainability and remanufacturing strategies by remanufacturing quality function deployment (RQFD). Environment, Development and Sustainability, 1-33.

Virglerova, Z., Addeo, F., \& Zapletalikova, E. (2020). Business dynamism in the world economy. Problems and Perspectives in Management, 18(3), 160-169. doi:10.21511/ppm.18(3).2020.14

Vizzon, J. S., Do Carmo, L. F. R. R. S., Ceryno, P. S., \& Fiorencio, L. (2020). Business process redesign: An action research. Gestao e Producao, 27(2). doi:10.1590/0104-530X4305-20

Vörösmarty, G., \& Dobos, I. (2020). A literature review of sustainable supplier evaluation with Data Envelopment Analysis. Journal of Cleaner Production, 264. doi:10.1016/j.jclepro.2020.121672

Yaya, S., Yaya, S., Otu, A., Otu, A., \& Labonté, R. (2020). Globalization in the time of COVID-19: Repositioning Africa to meet the immediate and remote challenges. Globalization and Health, 16 


\section{Acknowledgements}

This research was supported by the project, which has received funding from research and innovation programme of the Centro Internacional de Investigación y Desarrollo (CIID) Montería, Colombia.

Romel Ramón GONZÁLEZ-DÍAZ is the Professor of Business Enterprise and Innovation and Director of the CIID, Montería Colombia.

ORCID ID: $\underline{\text { https://orcid.org/0000-0002-7529-8847 }}$

\section{Santos Lucio GUANILO GÓMEZ}

ORCID ID: https://orcid.org/0000-0002-7611-937x

\section{Jorge SUÁREZ CAMPOS}

ORCID ID: https://orcid.org/0000-0002-7080-1423

\section{Ángel Eduardo ACEVEDO-DUQUE}

ORCID ID: https://orcid.org/0000-0002-8774-3282

\section{Elena CACHICATARI VARGAS}

ORCID ID: https://orcid.org/0000-0000-9843-432

Make your research more visible, join the Twitter account of ENTREPRENEURSHIP AND SUSTAINABILITY ISSUES: @Entrepr69728810

Copyright (C) 2021 by author(s) and VsI Entrepreneurship and Sustainability Center This work is licensed under the Creative Commons Attribution International License (CC BY). http://creativecommons.org/licenses/by/4.0/

\section{c) (i) Open Access}

